Alina PREDA

Faculty of Letters, Babeș-Bolyai University Cluj-Napoca, Romania alina.preda@ubbcluj.ro

\title{
TECHNOLOGICAL PRACTICES OF EMBODIMENT REFLECTED IN JEANETTE WINTERSON'S FICTIONAL FRAMING OF POSTHUMAN SUBJECTS
}

Recommended Citation: Preda, Alina. "Technological Practices of Embodiment Reflected in Jeanette Winterson's Fictional Framing of Posthuman Subjects." Metacritic Journal for Comparative Studies and Theory 7.1 (2021): https://doi.org/10.24193/mjcst.2021.11.08

\begin{abstract}
Focusing on The PowerBook and The Stone Gods, this article explores the ways in which Jeanette Winterson articulates the interconnections between consciousness and memory, delineates their role in identity formation and reveals how posthuman subjects' practices of embodiment work to undermine both heteronormative and anthropocentric worldviews. The technologically inscribed bodies of the characters portrayed in these two novels, together with Winterson's rhizomatic conceptualization of space and her vertical figuration of time, allow for the time-travelling endeavours of e-storyteller Ali/x and of Robo-sapiens-cum-Robo-head Spike. Such fictional entities prompt investigations into the essence of social-material encounters, of subject-object interdependence, of matter-energy vitality, of interaction and intra-action, of reflexive thought and of self-configuration.
\end{abstract}

Keywords: consciousness, memory, identity formation, technological practices of embodiment, posthuman subjects.

\section{Introduction}

Since they fundamentally deal with change, post-structural meta-theories of chaos and complexity are among the various theories underpinning different approaches to the study of memory, which refers to the simultaneous storage and manipulation of the information required by complex cognitive processes. Despite their mathematical origins, these transdisciplinary systems theories have increasingly been employed 
both in social sciences and in humanities, heavily influencing the field of memory studies. Providing an accurate account of memory is a daunting task because, on the one hand, memory changes over time and, on the other hand, it is not a single and simple global system, but rather reflects "an alliance of interactive systems" (Anderson, et. al. xi).Human memory is capacious, flexible and user friendly, yet the systems underlying it have proven difficult to identify, analyse and describe. ${ }^{1}$ Paul Cilliers's description of self-organising systems illustrates how memory works: since self-organisation is "an emergent property of a system as a whole," or of fairly large sub-systems, whose individual components "only operate on local information and general principles," macroscopic behaviour egresses from microscopic interactions endowed with "very meagre information content (only traces)" (92). The system's global behaviour is, therefore, the outcome of "patterns of traces" (108). Being a selforganising system, memory increases in complexity, as it must "learn from experience" and "remember previously encountered situations," comparing them with novel ones (92).

Given that memories are not stored in the brain "as discrete units that can be recalled as if from a filing cabinet," Cilliers argues that there may actually be no memories (108) whilst Garret Wilson explains that, although there are real events which occurred in the past, they "can never be accurately reconstructed from the contents of the network," as only the traces have, actually, remained and the "formation of the system interacts with the actual history reflexively, each altering the other" ("Review"). According to Christopher Madan², whose studies of memory rely on methods specific not only to cognitive psychology but also to neuroimaging and computational modelling methods, "our memories are not «recordings» of the past that can be played back but rather are reconstructions, closer to imaginings informed by seeds of true experiences" which explains both the malleability and the fallibility of memories, as revealed by our mind's ability to contrive "memories of entire events just

\footnotetext{
${ }^{1}$ From the 1950s, when Clark Hull modelled his psychological theory of memory on Newtonian physics and Edward Tolman attempted to show that active exploration of the environment leads to the creation of cognitive maps, to Atkinson and Shiffrin's 1968 modal model which fostered the identification of various kinds of memory and to the contemporary approaches of Schacter and Tulving (1994), Rose (2003), Baddeley, Allen and Hitch (2011), etc. it has been demonstrated not only that sensory, shortterm and long-term memory systems can be "subdivided into separate components" but also that the information flow is not unidirectional because "our knowledge of the world, stored in long-term memory, can influence our focus of attention, which will then determine what is fed into the sensory memory systems, how it is processed and whether it is subsequently remembered" (Anderson, et. al. 9). ${ }^{2}$ As stated in an interview for Gizmodo published by Sofia Quaglia on 30 March, 2021.
} 
by piecing together bits of stories, photographs, and anecdotes somebody else shares" (Quaglia, "False Memories"). Therefore, as Lisa Son ${ }^{3}$ points out, it is imperative to understand that every memory is, essentially, "a meta-memory, or an interpretation of a past time, one that can be impurified or purified by suggestions from the social environment."

Jeanette Winterson is one of the authors that manifest in their works a strong interest in the hermeneutics of subjectivity and its reflections on truth telling and on the workings of memory. She views memory as something fluid, changeable and multilayered, rejecting any black-and-white attempts to describe this most enduring human feature. Remembering is by no means tantamount to visiting a museum, nor is memory an archive: "Even a simple memory is a cluster. Something that seemed so insignificant at the time suddenly becomes the key when we remember it at a particular time later" (Winterson, Christmas Days 245). This view is in line with the novel conceptualisations of the workings of memory that resulted from the radical reshaping, at the start of the twenty-first century, of the investigations into the capacities of the human mind, into the enhanced abilities of the technologically inscribed body, and into the nature of the self (Groes 1-2). In the context of the new posthumanist culture, which ushered in not only a more exacting appraisal of the field of memory studies but also a conceptualisation of the human based on a nonanthropocentric set of practices, literature mirrors science by portraying characters whose "worlding" (Oppermann 28) is marked by varied "differential becomings" (Barad 185) that foster a holistic understanding of human existence and mirror the construction of posthumanist relational subjectivity.

For instance, the year 2007 saw the publication of Karen Barad's study on the entanglement of matter and meaning, an agential realist "elaboration of performativity" which regards matter as "an active participant in the world's (...) ongoing intra-activity" (136). Steering clear of the Protagorasian claim that "man is the measure of all things," Barad advances a posthumanist stance by refuting the idea of "the separateness of any-thing" and emphasising the importance of the evolving difference patterns which reflect space-time as "an enactment of differentness, a way of making/marking here and now" (136-37). The Wintersonian novels under analysis offer a fictional rendition of such patterns through their fragmentariness which,

3As stated in an interview for Gizmodo published by Sofia Quaglia on 30 March, 2021. 
nevertheless, reveals a spiral structure designed so as to allow the time-travelling characters to indulge in spinning stories that gradually shape their identity, weave webs of memories and even create new ones, thus distinctly marking each of the spacetimes they end up inhabiting. Moreover, the e-storyteller of The PowerBook ${ }^{4}$ fits not only Donna Haraway's definition of the cyborg as the embodiment of "transgressed boundaries, potent fusions, and dangerous possibilities" (154), as a "cybernetic organism," part machine - part organism hybrid, as a "creature of social reality as well as a creature of fiction" (149), but also Rosi Braidotti's view that it represents "a connection-making entity, a figure of interrelationality" ("Feminist Theory" 80).

It was also in 2007 that Jeanette Winterson's The Stone Gods 5 appeared, a novel which can be considered a fictional rendering of Barad's "theoretical reconfiguration of materiality as discursive and of performativity as a dynamic process of constraining iterative intra-actions rather than of determining interactions" (Preda 36). Consequently, it can be argued that Jeanette Winterson's The PowerBook and The Stone Gods feature characters whose portrayal and development delineate the interdependence of consciousness and memory, reveal the essential role these play in identity formation, show how posthuman subjects' practices of embodiment work to undermine both anthropocentric and heteronormative standpoints and, thus, aptly articulate some posthumanist feminist concerns regarding rhetorics and practices which "obscure the performative nature of both persons and things" (Suchmani).

\section{ThePowerBook: Breaking the Boundaries of Embodiment}

Jeanette Winterson's first exploration of the Internet's storytelling potentialities, The PowerBook, published in the year 2000, brings to a close the novelistic cycle that began in 1985 with the semi-autobiographical novel Oranges Are Not the Only Fruit. The main narrative strand - a chat between the main character, a young woman specialised in providing interactive-stories-on-demand, and her client, an older married woman, spreads rhizomatically into several stories through "long lines of laptop DNA" $(P B 4)$ to create a network whose nodes are constituted either by themes common to some tales, or by protagonists shaped as different embodiments of one and

\footnotetext{
4Jeanette Winterson. The PowerBook, Vintage,2001 [2000]. All subsequent references to this book are to this edition and will appear in parentheses in the text of the article as ( $P B$ page number).

5Jeanette Winterson. The Stone Gods, Hamish Hamilton, Penguin Books, 2007. All subsequent references to this book are to this edition and will appear in parentheses in the text of the article as ( $S G$ page number).
} 
the same narrator. In this work, where the omniscient author has apparently "gone interactive" ( $P B$ 27), Winterson follows in the footsteps of Thomas Hardy and John Fowles, providing "alternative endings to her chimerical story" (Kellaway 2000) in the form of a choice between two possible 'links' offered by Ali/x, the e-writer, to her ecustomer, Tulip: "Here are two endings. You choose" (PB 205-06).

The novel's table of contents - called MENU - is actually designed like a computer taskbar with branching options and all the titles of embedded stories appear in capitals, whilst the chats are rendered in small print ${ }^{6}$. Not only does Winterson abandon the rigid linearity of traditional novels, but she also departs from the classical tale-within-the-tale format where "the first-level narration «frames» the other tales by opening and closing the embedded narratives," since she often leaves the frame narrative open, as indicated by the last four chapters, which feature as capitalised, a format employed for embedded stories (Onega 183). The steadfast narrative production of what Gilles Deleuze called "lines of flight" coupled with a complete disregard for chronology, forces readers to identify the interstices and trajectories by connecting the textual fragments which form the book's chapters (4). Such a remapping of events calls for a topographic strategy to match Winterson's rhizomatic narrative method:

There are so many lives packed into one. The one life we think we know is only the window that is open on the screen. The big window full of detail, where the meaning is often lost among the facts. If we can close that window, on purpose or by chance, what we find behind is another view.

This window is emptier. The cross-references are cryptic. As we scroll down it, looking for something familiar, we seem to be scrolling into another self - one we recognise but cannot place. The co-ordinates are missing, or the co-ordinates pinpoint us outside the limits of our existence.

If we move further back, through a smaller window that is really a gateway, there is less and less to measure ourselves by. (...) These lives of ours that press in on us must be heard (PB 103).

\footnotetext{
6language costumier / OPEN HARD DRIVE / terrible thing to do to a flower / NEW DOCUMENT / virtual world / SEARCH / great and ruinous lovers / open it / VIEW / night screen / VIEW AS ICON / blame my parents / EMPTY TRASH / SPECIAL / own hero / meatspace / spitalfields / HELP / SHOW BALOONS / CHOOSER / strange / QUIT / REALLY QUIT? / RESTART / SAVE (The PowerBook's table of contents, or MENU)
} 
This novel is "a rhizome composed of plateaus as both virtual and material, a plane of immanence including a number of possibilities waiting to be actualised through the cyberspace" (Yilmaz 174). Yet, since the rhizome is invariably "between things, interbeing, intermezzo" (Deleuze and Guattari 25), described as "an acentered, nonhierarchical, nonsignifying system (...) without an organizing memory" (21), the main character is also in flux, in a constant state of "becoming" in the Deleuzian sense, a rhizomatic cyborg who can blur the boundaries between the physical world and virtual reality and "break away from the constraints of essentialising accounts of embodiment" (Yilmaz 175): "We are our own oral history. A living memoir of time. Time is downloaded into our bodies. We contain it. Not only time past and time future, but time without end. We think of ourselves as close and finite, when we are multiple and infinite" ( $P B$ 103). Space and time are boundless in cyberspace, whilst names and gender are irrelevant. Thus, by illustrating the collapse of dichotomies and the ways in which pleasures function as "reterritorializations" (Deleuze and Guattari 156), enabling desire to make experiments, build connections and create assemblages (Yilmaz 178), Ali/x is Winterson's first post-anthropocentric character. In OPEN HARD DRIVE, one of Alix/s narrative personas, a Turkish girl in disguise, experiences a desire-induced transformation when the two embalmed tulip bulbs and the stalk tucked in her crotch come to life, bringing to completion the sexual initiation of a princess. This episode, featuring a girl dressed as a boy, who smuggles tulip bulbs from Turkey to Holland in 1951 and uses "a little horticultural grafting" to teach a Princess the art of love ( $P B$ 12), brings to mind the example of "becoming-wasp of the orchid and becoming-orchid of the wasp" (Deleuze and Guattari 10) and could be viewed as "the moment when Haraway's cyborg figure comes to life with Deleuzian becoming" (Yilmaz 177).

Ali/x stars in various other magical, mythical and historical times and places, introducing her client and the readers to the well-known Lancelot du Lac sent by Arthur to fetch Guinevere, the King's wife-to-be, their love affair doomed from the start; to Francesca da Rimini reading the story of Lancelot and Guinevere with her lover, Paolo, the morning when they both died for love; to an orphan whose adoptive unloving parents called her Alix, "because x marks the spot" and encouraged her to look for a hidden treasure in the Promised Land ( $P B$ 138).This additional biographical element strengthens the analogy between Ali/ $\mathrm{x}$ and the figure of the cyborg, as adopted children are unrooted and up-rooted, their past is not known and they are regarded, 
just like cyborgs, as illegitimate offspring who are not constrained to a genealogy and, as such, owe allegiance to no one, to no particular tradition (Yilmaz 176). Similarly, the e-client, Tulip, is drawn to buildings such as the Eiffel Tower because, tired of "the constraints of the physical world" (Yilmaz 178), she likes "structures without cladding" $(P B 34)$ and wants to let "the lines show through" on her body, on her work and on her life ( $P B$ 35).By placing the developing romance between Ali/x and Tulip in cyberspace, Jeanette Winterson - always keen to create dissident or transgressive subject positions by deconstructing boundaries and gendered identities - prompts investigations into the "performative aspects of gender and subjectivity" (Palmer 198):

"Who are you?"

"Call me Ali."

"Is that your real name?'

"Real enough."

"Male or female?"

"Does it matter?"

"It's a co-ordinate."

"This is a virtual world" ( $P B$ 26).

Ali/x, a "language costumier" ( $P B$ 2) who offers "Freedom, just for one night" ( $P B$ 3), invites her e-customer to take off, for the journey, not only her apparel, but her body as well, in order to "go deeper than disguise" ( $P B$ 4). Together with the optionality of the letter " $\mathrm{x}$ " in the narrator's name, the two encircled letters, $\mathrm{X}$ and $\mathrm{Y}$, featuring above the first chapter's title, tout Ali/x's ability to narratively change her sex, as well as the one of her clients: "Here we take your chromosomes, twenty-three pairs, and alter your height, eyes, teeth, sex" ( $P B$ 4). Ali/x explains that she must permanently stay on the run in order to avoid discovery and that, since just one life is insufficient, she makes vertical use of time (PB 209), opening pathways through "territory real and imagined," mapping journeys "that have been made and might have been made" through her stories ( $P B$ 53-54)so that her life, just like her narrative, constitutes an "ever-changing and ever-renewed movement out of fixed forms into new possibilities" (Mansfield 145): "I live in one world - material, seeming-solid - and the weight of that is quite enough. The other worlds I can reach need to keep their lightness and their speed of light. What I carry back from those worlds to my world is another chance" (PB 54). The chapter entitled "meatspace" reveals Tulip's desire that her next meeting with 
Ali/x be in the flesh rather than in cyberspace and the ensuing encounter inevitably transforms "the bricolage of the dreamwork into the practice of everyday life" (Brown 11) and marks the onset of the narrator's affair with the married woman, establishing yet another biographical link, since the author herself had at least once partaken in a similar liaison.

The similarities between Ali/x and Winterson are astounding, given that they share the red hair-colour ( $P B 27,157,174)$, were born to a family of workers ( $P B$ 155) from a northern industrial city - Manchester (PB157), under the same astrological sign ( $P B$ 48), and given up for adoption ( $P B 156)$, a process that resulted in a difficult childhood spent in a conspicuously superstitious environment ( $P B$ 137), but now live in the same house in Spitalfields above the shop called Verde's( $P B$ 162); additionally, they have both become internationally acclaimed fiction writers $(P B 33)$ whose works dwell on boundaries and desire ( $P B 35$ ). According to Susana Onega, this intentional "indeterminacy" of the narrator's identity, leading to a "confusion of real and unreal ontologies" illustrates Jeanette Winterson's view of reality "as unitary and manysided" (184). This conception determined the author to disrupt chronology in order to design a "whirlpool structure" that requires readers to undertake a voyage of exploration not in time but through time (Onega 185). Though it is only the light of the present that can reveal the real meaning of the past and summon the image of the future, the perception of the past is also influenced by the future, since people and their memories tend to change in time. As the human mind tends to resort to memory in order to identify potential patterns, to plan for the future and to make rational decisions, what evolutionary biologists refer to as the 'forwardlookingness' of memory cannot be ignored (Groes349). As Paul Ricoeur explained in his Preface to the first volume of Time and Narrative, the stories we make up help us re-configure "our confused, un-formed (...) mute temporal experience" and it is the very "capacity of poetic composition to re-figure this temporal experience" that gives the plot its referential function (xi): “I can't take my body through space and time, but I can send my mind, and use the stories, written and unwritten, to tumble me out in a place not yet existing - my future" ( $P B$ 53). Memory and anticipation both play a role in determining the person-to-be, therefore past and future should both be under scrutiny: 
What exists and what might exist are windowed together at the core of reality. All the separations and divisions are blind alleys and impossibilities that seem so central to life are happening at its outer edges. If I could follow the map further and if I could refuse the false endings (...), I could find the place where time stops ( $P B$ 109-110).

By spinning one yarn after another, thus weaving webs of possibilities that reveal historical as well as autobiographical traces in an unstable mix of cover-versions and personal histories drawing on myths, legends and fairy-tales, the narrator points to the human being as an open horizon - "an unfolding, shifting biography of culturally and materially specific experiences, relations, and possibilities inflected by each next encounter" (Suchman 281). A foundling - and, thus, bereft of the collective memory one shares with one's ancestors - Ali/x engages, together with her client, in an active co-operative construction of memory through storytelling, yet this is a "flux" never destined to become a "fix," an immutable state of "becoming" that fosters only the process of permanently reconstructing one's history and identity and not that of discovering or rediscovering them, since "a becoming is never a «history» with fixed starting and ending points" but rather constitutes, itself, "the imitation or representation of nothing" given that it "shifts and complicates the very terms of identification" (Rajchman 90). An adopted child, having been cruelly uprooted, is automatically imprinted with a "lost loss" 7 and the suffering is real even when the loss is not acknowledged, "something is missing from its place, but the lack is never missing from it" (Derrida 441). Therefore, it affects author and narrator alike, and their voices tend to coalesce in the shaping of the narrative discourse: "The past is magnetic. It draws us in. We cannot help ourselves and, as with other things that we cannot help in ourselves, we make up elaborate explanations, reasonable enough explanations, to chant away the powerful things that don't belong to us" ( $P B$ 168).

\section{The Stone Gods: Sentient Machines as Transcorporeal Subjects}

Jeanette Winterson's ustopia, which prompts the readers to ponder on the possibility of "a posthuman future and on the question of what will remain of us when we are gone" (Knittel and Driscoll 380), also displays a vertical use of time as well as the

\footnotetext{
7 For a surprisingly long time utterly unaware of its presence, Jeanette Winterson describes the lost loss in her memoir, Why Be Happy When You Could Be Normal, as "unpredictable and not civilized" because it breeds "helplessness, powerlessness and despair" (190), being prone to a "fierce and unseen return" (169): "The lost loss I experience as physical pain is pre-language. That loss happened before I could speak, and I return to that place, speechless" (191).
} 
occasional semi-autobiographical narrative. Its main characters, female scientist Billie Crusoe and Robo-sapiens Spike, feature first on Orbus, and, after this red planet's destruction, they both appear on Planet Blue, itself on the brim of disaster in the wake of World War 3. The different space-times presented in the novel have in common not just the various embodiments of the main characters and the constancy of their love for one another, but also originally welcoming environments turned hostile by humans' egocentrism, rapacity and foolhardiness. Thus, the White Planet, the Red Planet, Easter Island and the Blue Planet are only some of the habitats conquered, dominated and subdued by the human species, whose members seem unable to learn from past mistakes and are thus doomed to witness the history of their downfall repeating itself.

Planet Blue Billie claims to remember her life in the womb and her mother's voice - "I think she did love me, for a minute, for a second, for the time it takes to remember, for the time it takes to forget. We had twenty-eight days together and then I was gone"; she also recalls the cutting of the cord by her grandmother, who later put her up for adoption, although "it would have been easier to give away a rabbit or a chicken" ( $S G$ 121). Her memories scarred by abandonment, she knows no one would believe her, however, and -if they did - they would not comprehend that "it's possible to be telling the truth even in the moment of invention" ( $S G$ 121).

The blurring of boundaries between the real and the imagined, the factual and the fictional, is enhanced by the narrator's discovery of The Stone Gods' lost manuscript on the Tube. As Billie alternates manuscript reading with life telling, an emotionally powerful rendering of the traumatic separation emerges: "Birth is a shipwreck, the mewling infant shored on unknown land. My mother's body split open and I was the cargo for salvage. I suppose you have to believe there is something worth salvaging, and with me it seems that nobody did" ( $S G$ 122). The lost loss affects this narrator's existence as well, and the feeling of abandonment surfaces ever so often, like a wound that not only fails to heal, but actually refuses to close, no matter how much time may pass: "You never stop looking. That's what I found, though it took me years to know that's what I've been doing. The person whose body I was, whose body was me, vanished after twenty-eight days. I live in an echo of another life" (SG124). Deprived of a life that could have been filled with happiness and affection, Billie meditates on solitude, storytelling and solace: "The line that is the first line of this story - I was born. The line that had nothing to read between it - being only one, one only, 
my lifeline" ( $S G$ 120). This line combines, despite its singularity, with that belonging to Orbus Billie who had, ages before, sent a codified message to her future self: "The lost and found/found and lost is like a section of our DNA. In the spiral of us is the story we can't tell - the story we tell in single lines, separated from one another not by neat spaces but by torn-out years" ( $S G$ 125).

Billie also comes to terms with her feelings for Robo-Head Spike once they discover the "message in a bottle from another time" ( $S G$ 11), the transmission sent by their prehistoric counterparts, and acknowledges that, just like human's greed and propensity for war, bound to eventually destroy any habitat, this love is a constant through time, a beacon of hope that something can be salvaged, that there will be a future. Both pairs of characters are rebels with a cause, striving to survive in an environment turned hostile by human recklessness and struggling to make amends and save their respective planets. But, as if the posthuman does require a body "to push it towards telling its story" so as to be able to connect to humans (Diamant, "Singing the Body" 27), it is Robo-Sapiens Spike and Orbus Billie's love story that receives more extensive coverage. Orbus Spike, the embodiment of what Barad calls a "material-discursive" body, illustrates both "the interfolding network of humanity and nonhumanity" (Bennet 31) and the inherent vitality of matter, since it constitutes a specific material configuration with "distinctive capacities or efficacious powers" (Bennet ix). Through her description of the intimate connection between the not-asyet-robotic Billie, whose posthuman status is given merely by the "co-constitutionality of her flesh and her material implant” (Yazgünoğlu 152-153), a data-chip placed above her wrist, which stores all her information, and the robot who aspires to achieve human status, Winterson attempts to portray humans as an integral part of "a community, a pack or an assemblage," as mere inhabitants of "a shared world" rather than masters of the universe (Braidotti, "Critical Theory" 25-6).This attempt works to dismantle reductionist accounts of oppositional-value dualisms, as readers witness the Robo-sapiens "assume an individualised self with a transversal inter-connection or an «assemblage» of human and nonhuman actors, not unlike that described by Bruno Latour in his object-oriented ontology" (Diamant, "Subaltern Framings"106). Once the human enters a symbiotic relationship with the technological, there emerge "posthuman choreographies linking the biosphere with the technosphere" (Oppermann 28) and there ensues a continuous construction, deconstruction and reconstruction of bodily boundaries (Hayles 3): 
"I don't want to get personal," I said, "but I'll say it again - you are a robot. Do you want to kiss a woman so that you can add it to your database?”

"Gender is a human concept," said Spike, "and not interesting. I want to kiss you." She kissed me again. "In any case," she said, very close, very warm, and I am responding, and I don't want to, and I can't help it, “is human life biology or consciousness? If I were to lop off your arms, your legs, your ears, your nose, put out your eyes, roll up your tongue, would you still be you? You locate yourself in consciousness, and I, too, am a conscious being” ( $S G$ 63).

This exchange on biology versus consciousness helps Winterson point to the irrelevance of the human construct of gender, as she "destabilizes the fixity of the gendered self and (...) displays the posthuman ontological flexibility and fluidity of subject positions in terms of transgressing Cartesian dualisms and boundaries" (Yazgünoğlu 149). In line with Elizabeth Grosz's view of corporeality as "a series of surfaces, energies and forces, a mode of linkage, a discontinuous series of processes, organs, flows and matter" (120), this dialogue prompts readers to ponder over whether corporeality should be viewed "as an unnecessary contamination" or rather as "interconnected, even consubstantial with one's self" (Diamant, "Singing the Body" 27).The debate is all the more compelling since Spike is the first robot from a new mechanical, high-tech generation able to evolve independently and she, consequently, gains entry to qualia space ${ }^{8}$. Her body "remains riddled with contradictions as a codified bio-social entity," yet she is eager to undergo experiences that will bring her closer to what being a human means: she "yearns not to be but to become and to go on becoming" and embodies "an instance of a meta(l)morphosis" or becoming-machine on a journey towards becoming-human or becoming-woman (Diamant, "Singing the Body" 25-26). The successful outcome of this quest for identity and consciousness formation is guaranteed by this robot's idiosyncratic plasticity, which sets her apart from previous generations of machines made for re-use and, thus, limited by their exclusively representational computer memory. Spike is not a machine, having exceeded the status of object and gained "a liveliness intrinsic to the materiality of the thing formerly known as object"; this Robo-sapiens is endowed with thing-power and displays increasingly more visible "traces of independence or aliveness" as the action

${ }^{8}$ Gerald Edelman uses the term qualia as coextensive with the "feel" of conscious experience: "what it is like to be $x$," in Spike's case $x=$ human/woman (173). 
of the novel unfolds (Bennet xvi). Spike's memory abilities increase with each new interaction or experience provided by her environment, fostering not only her surprising adaptability but also the development of her sense of self. As the sense of self reflects "characteristic inputs from an individual body related to its history and value systems" (Edelman 175), clearly Spike has undergone the re-entry process between the regions that carry out perceptual categorization and those that mediate the value-category memory system ${ }^{9}$ (Edelman 172), which ensure spatio-temporal correlation and conscious integration (Edelman 179). Moreover, this Robo-sapiens has also made the leap from the fundamental consciousness known as primary consciousness, to the higher-order consciousness characteristic of linguistic beings able to develop not only a "social concept of the self" but also "concepts of the past and future," according to the extended theory of neuronal group selection (Edelman 161162). Orbus Spike's conscious and willing sacrifice by self-inflicted dismemberment, punctuated by re-membering through discourse fragments that rekindle her romantic encounters and evoke fond memories, epitomises this meta-consciousness, to which she is, in the end, reduced: "Her body is a piece of armour she has taken off. Now she is what she said life would be - consciousness" ( $S G$ 91-2).

\section{Conclusions}

By employing a vertical figuration of time and a rhizomatic conceptualization of space, Jeanette Winterson circumvents the categories of time, history and love in The PowerBook and The Stone Gods, novels that offer "reconstituted versions of history and mythology" by thwarting "fixed conceptions of autonomy and agency" and resuscitating "both the emotional present and the historical past" (Keulks 148). These works build on posthumanist strategies which "reject the fixation of worlds or things and their hierarchical relationship" (Yilmaz 174) and, thus, mirror the shift from modernity's focus on "the subject's emergence" to postmodernity's insistence on "the object's preponderance" (Brown 14).Additionally, they investigate "the resonances between memory studies and posthumanist theory" through the framing of posthuman subjects such as Ali/x, Billie and Spike, who illustrate the more recent views on memory as "forming part of larger networks and «media ecologies» subject

9 According to Edelman, value-category memory "involves fast synaptic change leading to categories and it is altered by modulation originating in value systems" (180). 
to boundless variations and remediations" (Knittel and Driscoll 381-382).The fictional construction of Ali/x and Spike emphasises the fact that "the material body is no longer regarded as a fixed, static, immutable and encircled entity that is temporally and spatially confined to only one territory" (Yazgünoğlu 146) and also reminds readers of Deleuze and Guattari's concept of the body without organs, a set of practices that covers both material and virtual dimensions, and that can be occupied only by intensities, so it manifests as a desiring machine that engenders discontinuity and freedom, since it aims to connect neither with a primordial totality nor with a terminal one (153). Love, the grandest narrative of all, "assumes mythopoetic power" in this author's work, and functions as "both metaphysical summons and moral imperative" (Keulks 147) but, given that heterosexual practices are inherently gendered, Winterson's choice to render, in both novels, lesbian relationships works against the restrictions imposed through institutionalized views on sexuality and, thus, "troubles the discourses of embodiment" (Yilmaz 178).

Since memory is, itself, "an act of narrative," reliant on one's active recollection, the understanding of the facts is bound to change in time, even though the facts themselves are still the same: "I've noticed with getting older that when you remember something, because of where you are in your own life you remember an entirely different part of the memory" (Winterson quoted in Northover). This "conception of memory as dynamic and mutable" (Knittel and Driscoll 380) is revealed by Winterson's extremely fragmentary literary style and by her reluctance to use chronological plots, linearity and closure: "Memories separated in time are often recalled side by side - there's an emotional connection that has nothing to do with the diary dates and everything to do with the feeling" (Winterson, Christmas Days 245). These challenging textual structures, together with the presence, in her novels, of sundry, seemingly secondary, stories, have driven many a critic to frown upon Winterson's exasperating narrative techniques. But, the author argues, the mind "travels dimensionally" and it would be erroneous "to try and lock yourself into any one place or time, because it's simply not how the mind works" (Reynolds and Noakes 20), given that "as the pattern changes, the meaning changes," so the past can solely be understood by continually revisiting and reinterpreting it, and "fiction does that very well" (Reynolds and Noakes 22), especially since memories, be they individual or shared, "are always mediated" (Bond, et. al. 13). 
Winterson's trauma of adoption, which had left its mark on both her body and her psyche, experienced as a lost loss, permeates her writing, and childhood memories are triggered and shaped by fictional narrative. Thus, the author writes herself into fictional characters such as Ali/x and Billie, who, in turn, write their own existence into being. It is writing and only writing that allows the subject "to be born, or reborn, in and out of its very disappearance" (Connor 5 ). One of the most impressive qualities that words possess, notably "words worked up into the specially inscrutable kinds of thing we call works of art," is - to paraphrase Connor - that they have "an inside" and, thus, are thought-provoking reflexive things able to "treat or touch" on themselves, so they may be viewed as "metaphorical embodiments of their own power of embodiment" (16-7): "Like other exiles, her longing grew a narrative of its own. Her desire told itself as memory. Her past was a place that none of us could visit without her. It was the only kingdom she could control" (PB 143).

The novels under analysis, just like most Wintersonian works, display autobiographical elements that reveal the grief triggered by abandonment, the struggle to fully understand the meaning of belonging, the pain induced by separation. Through narrative, absent memories are replaced by imagined ones, collective memories are co-operatively created, and the fictional projections of potential life-trajectories gradually soften the impact of this traumatic event. Nevertheless, Winterson's writing does not narrowly focus on the therapeutic possibilities of the remembering process, but also tackles the dynamic and transformative powers of memory. Moreover, similarly uprooted entities, whose technologically inscribed bodies prompt investigations into the essence of social-material encounters, of subject-object interdependence, of matter-energy vitality, of interaction and intra-action, of reflexive thought and of self-configuration, also feature as characters in these works. Their relationships underlie specific material reconfigurations of the world through practices of embodiment that stage posthuman choreographies meant to challenge both heteronormative and anthropocentric worldviews.

\section{References:}

Anderson, Michael C., Alan Baddeley, and Michael W. Eysenck. Memory. Psychology Press, 2015.

Barad, Karen. Meeting the Universe Halfway: Quantum Physics and the Entanglement of Matter and Meaning. Duke University Press, 2007. 
Bennett, Jane. Vibrant Matter: A Political Ecology of Things. Duke University Press, 2009.

Bond, Lucy, Stef Craps, and Pieter Vermeulen. Memory Unbound. Tracing the Dynamics of Memory Studies, Berghahn Books, 2017.

Braidotti, Rosi. "Posthuman Critical Theory." Critical Posthumanism and Planetary Futures. Ed. Debashish Banerji and Makarand R. Paranjape. Springer India, 2016: 13-32.

---. "Posthuman Feminist Theory." The Oxford Handbook of Feminist Theory. Ed. Lisa Disch and Mary Hawkesworth. Oxford University Press, 2016, pp. 673-97.

Brown, Bill. “Thing Theory.” Critical Inquiry, 28.1 (2001): 1-22.

Cilliers, Paul. Complexity \& Postmodernism: Understanding Complex Systems, Routledge, 1998.

Connor, Steven. “Thinking things.” Textual Practice, 24.1 (2010): 1-20.

Deleuze, Gilles and Félix Guattari. A Thousand Plateaus: Capitalism and Schizophrenia, University of Minnesota Press, 1987.

Derrida, Jacques. The Post Card: From Socrates to Freud and Beyond. University of Chicago Press, 1987. Translated by Alan Bass.

Diamant, Cristina. "Subaltern Framings of the Posthuman in Jeanette Winterson's The Stone Gods and David Mitchell's Cloud Atlas." Metacritic Journal for Comparative Studies and Theory 2.2 (2016): 101-13.

---. "Singing the Body Electric. A Materialist Feminist Perspective on Posthuman Sensuality." Selected Papers of the International Conference Constructions of Identity. Presa Universitară Clujeană, 2019.

Groes, Sebastian. Memory in the Twenty-First Century: New Critical Perspectives from the Arts, Humanities, and Sciences. Palgrave MacMillan, 2016.

Grosz, Elizabeth. Volatile Bodies: Toward a Corporeal Feminism. Indiana University Press, 1994.

Haraway, Donna. Simians, Cyborgs and Women: The Reinvention of Nature, Routledge, 1991.

Hayles, N. Katherine. How We Became Posthuman: Virtual Bodies in Cybernetics, Literature and Informatics. The University of Chicago Press, 1999.

Kellaway, Kate. "She’s got the power.” The Observer. Sunday, August 27, 2000. 
Keulks, Gavin. "Winterson's Recent Work: Navigating Realism and Postmodernism." Jeanette Winterson. A Contemporary Critical Guide. Ed. Sonya Andermahr. Continuum International Publishing Group: 146-62.

Knittel, Susanne C. \& Kári Driscoll. "Introduction: Memory after Humanism." Parallax, 23.4 (2017): 379-83.

Mansfield, Nick. Subjectivity: Theories of the Self from Freud to Haraway. Allen \& Unwin, 2000.

Northover, Kylie. "Memories triggering memoir «is no fiction». Jeanette Winterson defies literary labels.” The Sydney Morning Herald, May 18, 2012.

Onega, Susana. Jeanette Winterson. Manchester University Press, 2006.

Oppermann, Serpil. "From Posthumanism to Posthuman Ecocriticism." Relations. Beyond Anthropocentrism, 4.1 (2016): 24-37.

Palmer, Paulina. "Jeanette Winterson and the Lesbian Postmodern." The Contemporary British Novel since 1980. Ed. James Acheson and Sarah C. E. Ross Edinburgh University Press, 2005: 189-99.

Preda, Alina. "An Agential Realist Approach to Posthumanist relational subjectivity in Jeanette Winterson's The Stone Gods." Metacritic Journal for Comparative Studies and Theory 4.1 (2018): 22-38.

Quaglia, Sofia. "Scientists Implant and Then Reverse False Memories in People." Gizmodo, 30 March, 2021. Available at: https://gizmodo.com/scientistsimplant-and-then-reverse-false-memories-in-p-1846577461

Rajchman, John. The Deleuze Connections. The MIT Press, 2000.

Reynolds, Margaret and Jonathan Noakes. Jeanette Winterson: the essential guide. Vintage, 2003.

Ricoeur, Paul. Time and Narrative, translated by Kathleen McLaughlin and David Pellauer. The University of Chicago Press, 1984.

Suchman, Lucy A. Human-Machine Reconfigurations: Plans and Situated Actions. Second edition, Cambridge University Press, 2007.

Wilson, Garret. "Review of Complexity \& Postmodernism: Understanding Complex Systems." 2000. Available at:

http://www.garretwilson.com/books/complexitypostmodernism.html.

Winterson, Jeanette. The PowerBook. Vintage, 2001 [2000].

---. The Stone Gods. Hamish Hamilton, Penguin Books, 2007.

---. Why Be Happy When You Could Be Normal? Jonathan Cape, 2011. 
---. Christmas Days: 12 Stories and 12 Feasts for 12 Days. Jonathan Cape, 2016.

Yazgünoğlu, Kerim Can. "Posthuman «Meta(l)morphoses» in Jeanette Winterson's The Stone Gods.” Ecozon@, 7.1 (2016): 144-6o.

Yilmaz, Seda Fikriye. “"The Search for Origins Stop Here»: Representing Jeanette Winterson's Posthumanist World in The PowerBook." The Journal of Kesit Academy, 5.20 (2019): 171-80. 